\title{
Pengembangan Media Pembelajaran Berbasis Android pada Mata Kuliah Pembelajaran Matematika SD
}

\author{
Eko Andy Purnomo ${ }^{1 *}$, Suparman ${ }^{2}$ \\ ${ }^{1}$ Universitas Muhammadiyah Semarang, ${ }^{2}$ UPBJJ UT Semarang \\ *ekoandy@unimus.ac.id
}

Diterima: Oktober 2019. Disetujui: Desember 2019. Dipublikasikan: Januari 2020.

\begin{abstract}
ABSTRAK
Perkembangan teknologi yang sangat cepat dan berbasis dengan big data dapat dimanfaatkan dalam bidang pendidikan khususnya pembelajaran. Melalui pemanfaatan teknologi maka Universitas Terbuka mengembangkan Sistem Belajar Jarak Jauh (SBJJ). SBJJ memiliki tingkat fleksibilitas tinggi dan lebih menekankan pada student centered learning. Salah satu media yang dapat dikembangkan dalam tutorial tatap muka dengan tutorial berbasis sistem android. Pemanfaatan android pada pembelajaran dapat berisi rangkuman materi dan peta konsep serta mengadakan pretest, tugas tutorial, mengerjakan latihan soal, serta posttest. Tujuan pada penelitian ini adalah mengembangkan media pembelajaran berbasis android pada mata kuliah Pembelajaran Matematika SD. Pengembangan media pembelajaran menggunakan model 4-D dari Thiagarajan, Semmel, dan Semmel. Metode pengumpulan data dengan wawancara, observasi, dan angket. Hasil pengembangan media pembelajaran berbasis android pada mata kuliah Pembelajaran Matematika SD termasuk media dengan kategori valid. Validasi media oleh pakar dengan rata-rata 4,07 dengan kategori valid, hasil uji keterbacaan kecil menghasilkan penilaian 3,92 dengan kategori valid, dan hasil uji keterbacaan besar menghasikan nilai 4,04 dengan kategori sangat valid.

Kata kunci: android, media pembalajaran, pembelajaran matematika SD.
\end{abstract}

\begin{abstract}
The rapid technology development and based on big data can be utilized in education especially learning. Through the utilization of technology, open university developed a remote learning system (SBJJ). SBJJ has a high level of flexibility and more emphasis on student centered learning. One of the media that can be developed in tutorial with android system. Android utilization on learning can contain a summary of the material and the concept map as well as conduct pretest, tutorial assignments, work on the problem, and posttest. The purpose of this research is to develop an android-based learning media in elementary school mathematics learning which are described specifically. The development of media learning used 4-D models from Thiagarajan, Semmel and Semmel. Further, the data collection methods were interviews, observations, and questionnaires. Moreover, the research result were the development of android-based learning media on the learning course of Elementary Mathematics Education with valid categories. The results of the media development are as follows a). Media validation by an expert got an average of 4.07 which had a valid category, b). The results of small legibility tests resulted in a 3.92 assessment with valid.
\end{abstract}

Keywords: android, blended learning, learning media, mathematic for elementary school.

How to Cite: Purnomo, E. A. \& Suparman. (2020). Pengembangan Media Pembelajaran Berbasis Android pada Mata Kuliah Pembelajaran Matematika SD. Journal of Medives: Journal of Mathematics Education IKIP Veteran Semarang, 4(1), 187-195. 


\section{PENDAHULUAN}

Memasuki perkembangan era industri 4.0, perlu kita sikapi dengan tepat. Perkembangan teknologi yang sangat cepat dan berbasis dengan big data dapat dimanfaatkan dalam bidang pembelajaran. Penerapan teknologi dalam pembelajaran merupakan suatu keharusan di era sekarang. Melalui pemanfaatan teknologi maka UT mengembangkan SBJJ. SBJJ memiliki tingkat fleksibilitas tinggi dalam mengeliminasi berbagai keterbatasan yang selama ini dihadapi oleh pendidikan tatap muka (Gunawardena \& McIsaac, 2004; Baggaley, Belawati \& Malik, 2010) dan lebih menekankan pada student centered learning daripada teacher centered learning (Simonson, Smaldiro, Albright and Zvacek, 2012) dan blended learning.

Era perkembangan ilmu pengetahuan dan teknologi yang begitu pesat. Pemanfaatan teknologi sangat berdampak pada pembelajaran di antaranya adalah sebagai berikut. 1) Memfasilitasi kegiatan belajar, salah satunya dengan memperkaya sumber dan media pembelajaran (Daryanto, 2010). 2) Media pembelajaran e-learning dapat meningkatkan keterampilan proses dan kemampuan pemecahan masalah mahasiswa (Mawarsari \& Purnomo, 2016). Media pembelajaran dapat meningkatkan aktifitas dan efektivitas pembelajaran (Purnomo, Dalyono \& Handayani, 2018). 3) Berdampak positif terhadap peserta didik (Maunah, 2016). 4) Memberikan peluang kepada peserta didik untuk membuat dugaan matematis (Paradesa, 2010). Salah satu media pembelajaran yang banyak dikembangkan dalam SBJJ adalah media pembelajaran android.

Pembelajaran berbasis android dapat diterapkan pada tutorial tatap muka, salah satunya pada mata kuliah Pembelajaran Matematika SD. Tujuan diajarkan mata kuliah ini untuk membekali mahasiswa dengan pengetahuan dan keterampilan yang akan membantu mahasiswa dalam melaksanakan proses pembelajaran matematika di SD. Mata kuliah pembelajaran SD berisi pembelajaran matematika berdasarkan KBK, Media dan Bahan Manipulatif dalam Pembelajaran Matematika SD, Bilangan Bulat, Bilangan Rasional dan Desimal, Bangun Ruang, Luas dan Volume Bangun Ruang, Sistem Kordinat, Trigonometri, Bilangan Berpangkat, dan Logaritma (Muhsetyo dkk, 2011).

Berdasarkan observasi pada pokjar Boja dan pokjar Kaliwungu pada 2018.1 kabupaten Kendal dapat disimpulkan bahwa mahasiswa banyak mengalami kesulitan pada mata kuliah Pembelajaran Matematika SD. Mahasiswa banyak mengalami kesulitan pada materi Bilangan Rasional dan Desimal, Sistem Kordinat, Trigonometri, Bilangan Berpangkat, dan Logaritma. Kesulitan ini dikarenakan 1) pada materi tersebut tidak diajarkan di SD sehingga banyak mahasiswa yang sudah lupa materi itu, 2) tingkat kesulitan materi trigonometri dan logaritma sangat tinggi, dan 3) waktu yang sangat terbatas dalam mempelajari materi tersebut. Melalui hasil observasi tersebut diperlukan bahan ajar yang dapat membatu mahasiswa dalam mempelajari materi tersebut. Mengatasi permasalahan belajar dengan menekankan belajar secara kontekstual melalui 
kegiatan-kegiatan yang kompleks (Purnomo, Rohman \& Budiharto, 2015).

Media pembelajaran berbasis android pada mata kuliah Pembelajaran Matematika SD dirancang dengan memperhatikan karakteristik materi, karakteristik mahasiswa UT, dan pelaksanaan tutorial tatap muka. Materi dalam media pembelajaran mengkombinasikan pada modul Pembelajaran Matematika $\mathrm{SD}$, materi latihan mandiri yang ada di website UT dan literatur lain yang sesuai dengan materi. Melalui kombinasi ketiga materi tersebut nantinya akan membuat materi dalam media pembelajaran semakin lengkap. Karakteristik mahasiswa UT sebagian besar sudah mengajar di SD sehingga materi terkait matematika SD bisa langsung didesain untuk menjadi tugas. Materi yang tidak diajarkan di SD maka dalam media akan lebih dititikberatkan.

Pengelompokan materi juga didasarkan karakteristik pertemuan tutorial tatap muka. Pada menu latihan, pengelompokan disesuaikan dengan menu materi. Setiap materi akan ada latihan soal dan pembahasannya. Pada evaluasi terdapat evaluasi 1 dan 2 . Evaluasi 1 merupakan pre test dan evaluasi 2 berisi post test. Dalam evaluasi tersebut mahasiswa bisa langsung mengetahui hasil evaluasi.

Selain melihat hasil media pembelajaran ini didesain sedemikian rupa sehingga dapat melihat aktifitas dari mahasiswa. Data base dapat menampilkan mahasiswa yang sudah login/masuk dalam sistem media pembelajaran. Database juga bisa menampilkan aktifitas mahasiswa dalam mempelajari materi yang ada. Kemampuan yang lainnya juga bisa melihat seberapa lama mahasiswa mempelajari materi tersebut dan kapan waktu mempelajarinya sehingga dapat menganalisis aktifitas mahasiswa. Berdasarkan hal tersebut maka akan dikembangkan media pembelajaran berbasis android pada mata kuliah Pembelajaran Matematika SD.

\section{METODE}

Penelitian ini merupakan research and development yang menghasikan suatu produk tertentu (Sugiyono, 2013). Produk yang dihasilkan media pembelajaran berbasis android. Model pengembangan yang digunakan adalah model 4-D dari Thiagarajan, Semmel, dan Semmel yang diringkas. Model pengembangan terdiri dari 4 tahap yaitu: define, design, develop, dan disseminate. Pada penelitian ini menggunakan 3 tahap, dengan menghilangkan tahap disseminate. Metode pengumpulan data dengan triangulasi data yaitu angket, observasi dan wawancara. Analisis data yang dipakai deskriptif yaitu suatu cara nalisis data dengan jalan menyusun secara sistematis dalam bentuk katakata, kategorikategori mengenai suatu objek sehingga diperoleh simpulan (Agung, 2012).

\section{HASIL PENGEMBANGAN}

Tahapan pelaksanaan pengembangan dijelaskan sebagai berikut.

\section{Pendefinisian (Define)}

Pada tahap ini ada beberapa tahapan yaitu: 1) analisis masalah dan alternatif terhadap pengembangan media pembelajaran, 2) analisis karateristik mahasiswa UT, 3) analisis materi Pem- 
belajaran Matematika SD, 4) menentukan tujuan mata kuliah, dan 5) menentukan indikator mata kuliah.

Berdasarkan hasil angket dan wawancara dapat disimpulkan bahwa 1) mahasiswa belum memanfaatkan fasilitas pembelajaran yang ada seperti tutorial online, latihan mandiri dan perpustakaan online, 2) karakteristik mahasiswa UT sebagian besar sudah bekerja atau mengajar di SD, 3) melalui kegiatan mengajar mahasiswa mempunyai waktu yang sangat terbatas dalam mempelajari materi, 4) pada umumnya mahasiswa mempelajari materi perkuliahan yang diajarkan di SD.

Mata kuliah pembelajaran SD berisi Pembelajaran Matematika berdasarkan KBK, Media dan Bahan Manipulatif dalam Pembelajaran Matematika SD, Bilangan Bulat, Bilangan Rasional dan Desimal, Bangun Ruang, Luas dan Volume Bangun Ruang, Sistem Kordinat, Trigonometri, Bilangan Berpangkat dan Logaritma. Permasalahan yang ada di Mata kuliah Pembalajaran Matematika SD ini mahasiswa banyak mengalami kesulitan pada materi Bilangan Rasional dan Desimal, Sistem Kordinat, Trigonometri, Bilangan Berpangkat dan Logaritma. Kesulitan ini dikarenakan 1) pada materi tersebut tidak diajarkan di SD sehingga banyak mahasiswa yang sudah lupa materi itu, 2) tingkat kesulitan materi trigonometri dan logaritma sangat tinggi, dan 3) waktu yang sangat terbatas dalam mempelajari materi tersebut. Berdasarkan hal di atas maka ditentukan tujuan mata kuliah yaitu mahasiswa menguasai materi matematika SD dan mampu menerapkan berbagai ragam/model pembelajaran matematika di SD.

\section{Perancangan (Design)}

Tujuan tahap ini adalah untuk menyiapkan prototipe media pembelajaran. Tahap ini terdiri dari 4 langkah yaitu penyusunan tes, pemilihan media, pemilihan format, dan desain awal. Langkah-langkahnya adalah penyusunan tes beracuan patokan, pemilihan media, pemilihan format, dan rancangan awal. Berdasarkan kompetensi mata kuliah
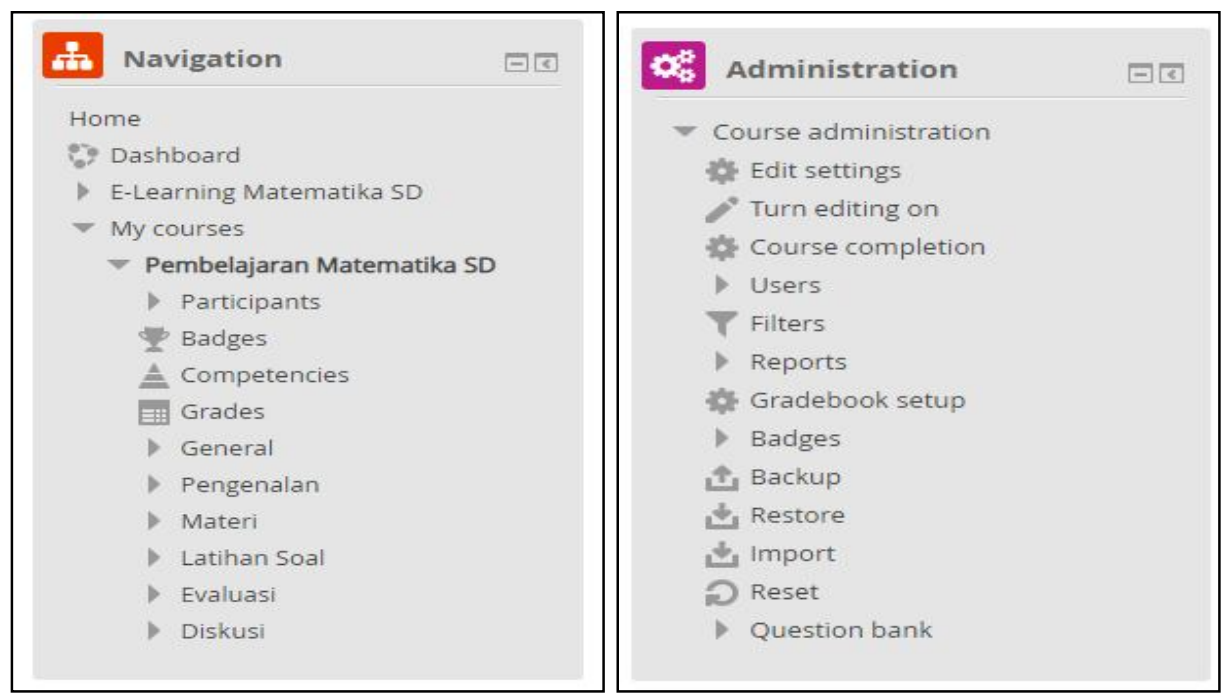

Gambar 1. Perancangan Awal Media Pembelajaran 

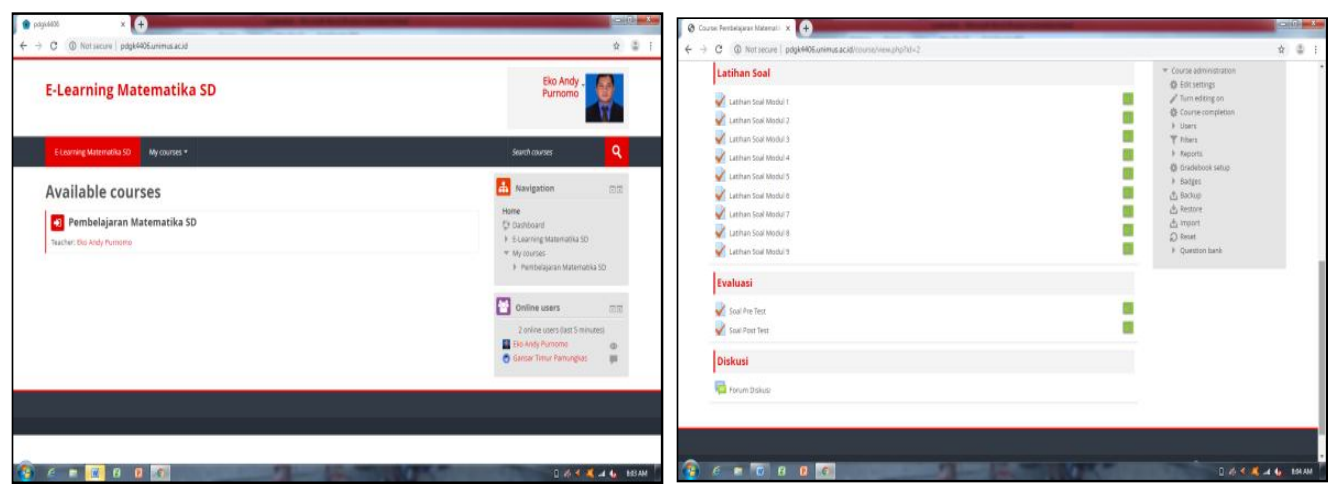

Gambar 2. Perancangan Menu Latihan Soal

Pembelajaran Matematika SD akan dibuat media pembelajaran. Perancangan media dapat dilihat pada Gambar 1.

Perancangan media dibuat tertutup artinya hanya yang mempunyai akun yang dapat menggunakan media pembelajaran. Hal ini dengan tujuan agar hanya mahasiswa saja yang dapat menggunakan media pembelajaran. Pada media pembelajaran dibagi menjadi 2 user yaitu user dosen dan mahasiswa. Pada user dosen diberikan menu lengkap yaitu 2 yaitu administration dan navigation. Menu navigation berisi participants, bages, competences, grades, dan general. Sedangkan pada menu administrator berisi: edit settings, filters, reports, gradebook setup, badges, backup, restore, import, reset, dan question bank. Sedangkan pada akun mahasiswa hanya terdapat menu navigation. Melalui akun dosen bisa melihat aktifitas dalam media pembelajaran seperti aktifitas mahasiswa, nilai mahasiswa dan capaian belajar mahasiswa.

Pada pembuatan media ini terdapat beberapa yang disesuaikan dengan kebutuhan mahasiswa. Menu utama dalam media pembelajaran dibagi menjadi 1) pengenalan yang terdiri dari kata pengantar, sumber/daftar pustaka, dan biodata; 2) materi mata kuliah Pembelajaran Matematika SD yang terdiri dari 9 modul yang disesuaikan dengan modul
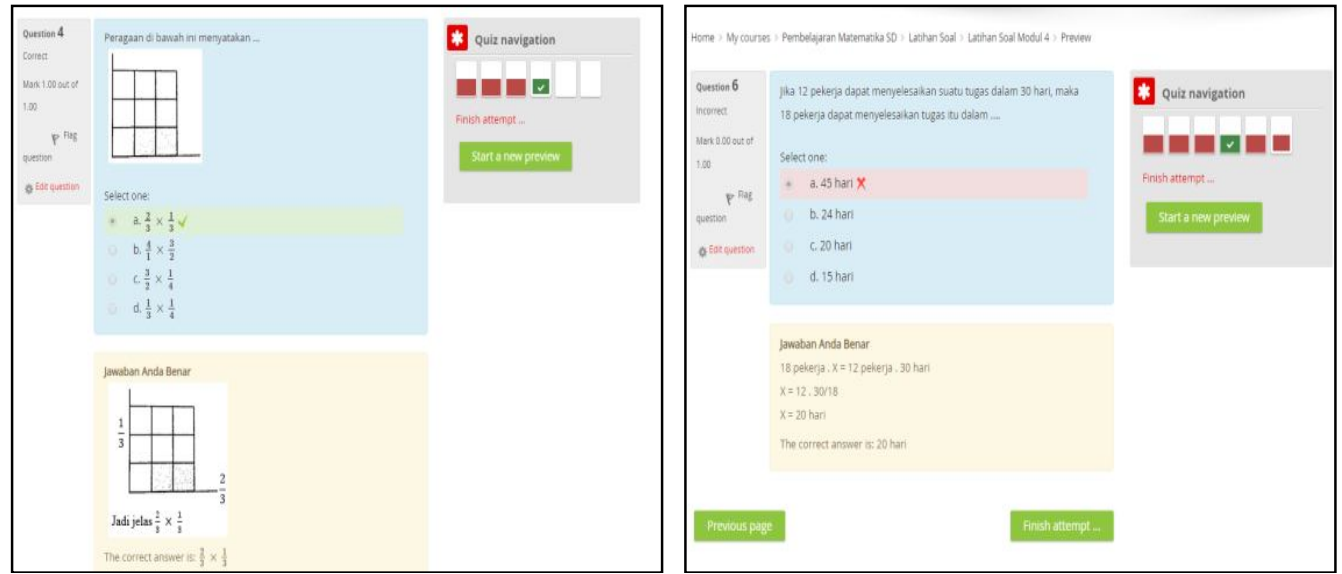

Gambar 3. Perancangan Menu Latihan Soal 

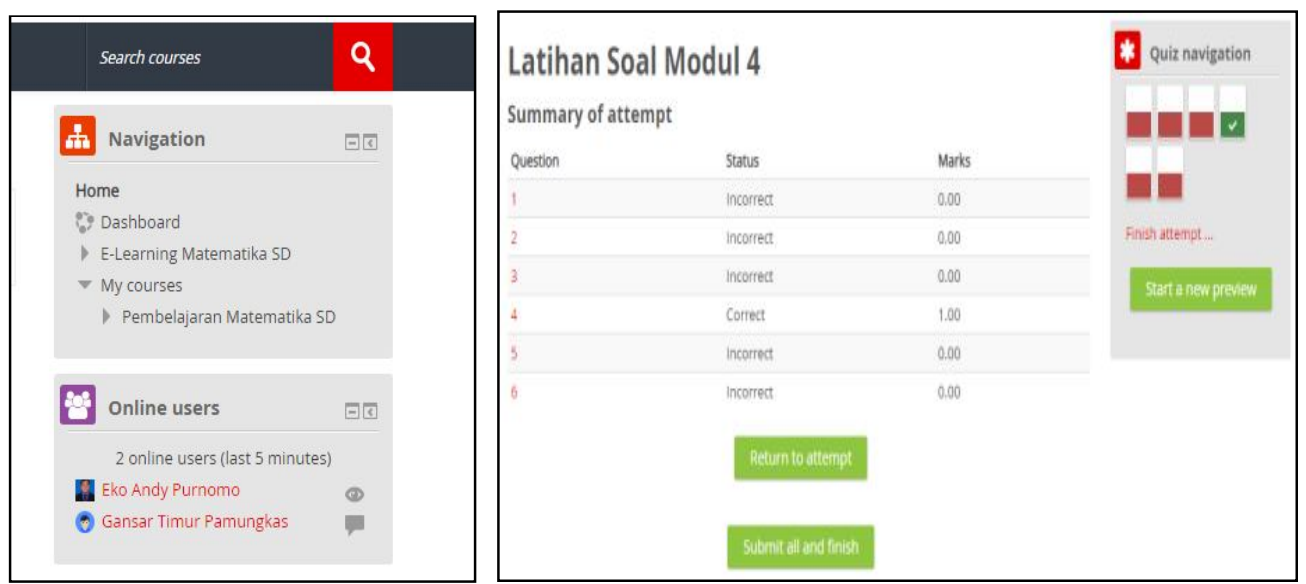

Gambar 4. Perancangan Menu Online User dan Penilaian Latihan

mahasiswa; 3 ) latihan soal yang dikemas dalam 9 modul; 4) evaluasi yang terdiri dari pretest dan postes; dan 5) diskusi. Materi pengenalan ini berisi perkenalan media pembelajaran mata kuliah Pembelajaran Matematika SD. Dalam pengenalan terbagi menjadi 3 bagian yaitu kata pengantar, sumber/daftar pustaka, dan biodata. Pada menu materi dibagi menjadi 9 modul, hal ini disesuaikan dengan modul mata kuliah Matematika yang telah dijadikan referensi selama ini.

Perancangan menu latihan dibagi menjadi 9 bagian/menu yang disesuaikan dengan modul pada soal materi. Keunggulan pada menu latihan ini adalah pada soal yang bervariasi dan mahasiswa dapat melihat apakah jawabannya benar atau salah. Pada bagian checking dapat dilihat jawaban yang benar beserta cara penyelesaiannya. Bagi mahasiswa yang jawabannya salah dapat mempelajari di bagian mana kesalahan dilakukan mahasiswa. Menu ini dapat memberi kesempatan langsung mahasiswa dapat evaluasi materi tersebut.

Keunggalan lain yang dimiliki media pembelajaran ini, kita dapat mengetahui berapa skor hasil latihan soal dan soal mana saja yang jawabanya salah. Nilai latihan modul bisa langsung dilihat pada saat mahasiswa meng-klik jawaban soal terakhir. Melalui menu ini diharapkan mahasiswa dapat mengukur seberapa besar penguasaan materi per modul. Selain itu ada menu dosen kita dapat mengecek siapa saja yang online pada saat itu. Dengan adanya menu ini diharapkan mahasiswa dapat lebih aktif untuk belajar online.

Tabel 1. Hasil Validasi Media

\begin{tabular}{cccc}
\hline No. & Validator & Keahlian/ Kepakaran & Rata-rata Hasil Validasi \\
\hline 1 & Validator 1 & Matematika SD & 4.1 \\
2 & Validator 2 & Evaluasi Pembelajaran & 3.9 \\
3 & Validator 3 & Media Pembelajaran & 4.2 \\
& \multicolumn{2}{c}{ Rata-rata } & 4.07 \\
& Kategori & Valid dengan sedikit revisi \\
\hline
\end{tabular}




\section{Pengembangan (Develop)}

Hasil perancangan media pembelajaran kemudian dilanjutkan dengan tahap pengembangan. Pada tahap pengembangan ini terdiri dari validitas ahli dan uji keterbacaan. Validator ahli ada 3 yaitu ahli materi matematika SD, evaluasi pembelajaran, dan media pembelajarann. Hasil validasi dapat dilihat pada Tabel 1.

Masing masing ahli hasil rataratanya untuk ahli matematika SD 4,1; ahli evaluasi pembelajaran 3,9; dan ahli media pembelajaran 4,2. Dengan ratarata 4,07 dengan kategori valid dengan sedikit revisi.

Setelah validasi pakar/ahli langkah selanjutnya dengan uji keterbacaan. Uji keterbacaan dibagi menjadi 2 yaitu uji keterbacaan skala kecil dan skala besar. Hasil uji keterbacaan kecil menghasilkan penilaian 3,92 dengan kategori valid dapat digunakan dengan sedikit revisi. Langkah selanjutnya adalah uji coba keterbacaan skala besar. Hasil uji keterbacaan besar menghasikan nilai 4,04 dengan kategori sangat valid dapat digunakan dengan sedikit revisi.

\section{PEMBAHASAN}

Proses pengembangan media pembelajaran berbasis android telah dilaksanakan sesuai dengan teori pengembangan Thiagarajan, Semmel, dan Semmel. Pada tahap pendefinisian dapat disimpulkan tentang karakteristik mahasiswa UT, materi mata kuliah Pembelajaran Matematika SD yang akan dipakai dalam mendesain media pembelajaran. Melalui karakteristik tersebut untuk menentukan kesesuaian materi dengan tujuan pembelajaran. Hal ini sesuai dengan pendapat Musclih (2010) bahan ajar yang memiliki kelayakan isi apabila terdapat kesesuaian kompetensi utama dan materi pendukung pembelajaran.

Tahap desain media secara garis besar media pembelajaran dibagi menjadi 5 menu utama yang terdiri dari 1) kata pengantar, sumber/daftar pustaka, dan biodata; 2) materi mata kuliah Pembelajaran Matematika SD yang terdiri dari 9 modul yang disesuaikan dengan modul mahasiswa; 3 ) latihan soal yang dikemas dalam 9 modul; 4) evaluasi yang terdiri dari pretest dan postes; dan 5) diskusi. Melalui kelengkapan media ini diharapkan mahasiswa dapat memanfaatkan dalam pelaksanaan tutorial.

Pada tahap pengembangan terdiri dari validitas ahli dan uji keterbacaan. Berdasarkan hasil validasi didapatkan rata-rata skor 4,07 dengan kategori valid dengan sedikit revisi. Hasil validasi ini menunjukkan bahwa media pembelajaran memiliki kelayakan baik isi maupun konstruk. Hasil uji keterbacaan kecil menghasilkan 3,92 dan uji coba keterbacaan skala besar nilai 4,04. Bahan ajar yang memberi kemudahan kepada peserta didik mempunyai keterbacaan tinggi (Kurniawan, 2014).

Berdasarkan pengembangan media pembelajaran dapat diketahui keunggulan dari media pembelajaran ini 1) media pembelajaran disesuaikan dengan modul yang telah digunakan mahasiswa UT; 2) mempunyai menu yang variatif dan disesuaikan dengan kebutuhan mahasiswa; 3) mempunyai materi yang lengkap dan banyak referensi latihan soal dan evaluasi soal; 4) dapat mengetahui 
aktifitas mahasiswa dalam menggunakan media/mempelajari materi serta kemampuan mahasiswa dalam berdiskusi.

Media pembelajaran ini dilengkapi dengan soal-soal yang variatif. Pada soal evaluasi disediakan 120 soal yang akan muncul sebanyak 40 secara acak berdasarkan jumlah modul yang ada. Selain itu soal akan secara acak keluar sehingga mahasiswa tidak bisa memprediksi soal yang akan keluar. Hal ini akan berdampak positif karena walaupun mahasiswa sering mengerjakan soal evaluasi maka soal yang muncul akan berlainan dengan soal evaluasi sebelumnya.

Adanya database aktifitas mahasiswa maka dosen dapat memberikan umpan balik kepada mahasiswa sesuai dengan kebutuhan. Hal ini sesuai dengan Holland (2011) dengan memonitor jenis informasi postingan mahasiswa dapat memberikan umpan balik yang berguna untuk mendukung kemajuan yang baik. Berdasarkan kelebihan-kelebihan di atas dapat disimpulkan bahwa media pembelajaran berbasis android dapat membantu mahasiswa dalam meningkatkan keaktifan dan hasil belajar pada Mata kuliah Pembelajaran Matematika SD.

\section{PENUTUP}

Berdasarkan hasil pengembangan dapat disimpulkan sebagai berikut.

1. Validasi media oleh pakar dengan rata-rata 4,07 dengan kategori Valid.

2. Hasil uji keterbacaan kecil menghasilkan penilaian 3,92 dengan kategori valid.

3. Hasil uji keterbacaan besar menghasikan nilai 4,04 dengan kategori sangat valid.

\section{DAFTAR PUSTAKA}

Agung, A.G. (2012). Metodologi Penelitian Pendidikan. Singaraja: Undiksha

Baggaley, J., Belawati, T., \& Malik, N. 2010. Distance education in Asia Pacific: Diambil tanggal 4 Juli 2014, dari http://web.idrc.ca/en/ev -140836-201-1-DO_TOPIC.html

Daryanto. 2010. Media Pembelajaran. Yogyakarta: Gava Media.

Gunawardena, C.N., \& McIsaac, M.S. (2004). Distance education. dalam D. H. Jonassen (Ed.), Handbook of research on educational communications and technology (2nd ed., h. 355-395). Mahwah, NJ: Lawrence Erlbaum.

Holland, C., \& Muilenburg, L. (2011), March. Supporting student collaboration: Edmodo in the classroom. In Society for Information Technology \& Teacher Education International Conference (Vol. 2011, No. 1, pp. 3232-3236).

Kurniawan, Khaerudin. 2014. Handout Mata kuliah Menulis Buku Ajar Ilmiah.

File.upi.edu./Direktori/FPBS/JUR ../Handout_Buku_Ajar.pdf

Mauah, B. (2010). Dampak Regulasi di Bidang TIK terhadap Perilaku Sosial Siswa di Sekolah Menengah Kejuruan. Cakrawala Pendidikan. TH XXXV, No. 2 : 176-186.

Mawarsari, V.D \& Purnomo, E.A. (2015). Pemanfaatan Software Geogebra Berbantuan E-Learning dalam Pembelajaran Geometri. Jurnal Karya Pendidikan Matematika. 4 (2). https://jurnal.unimus.ac.id/index.p hp/JPMat/article/view/3166/3052 
Muhsetyo, dkk. 2011. Pembelajaran Matematika SD. Jakarta : Universitas Terbuka.

Muslich, Mansur. 2010. Text Book Writing. Jogjakarta : Ar-Ruz Media.

Paradesa, R. Zulkardi., Darmawijoyo. (2010). Bahan Ajar Kalkulus 2 Menggunakan Macro Media Flash dan Maple di STKIP PGRI Lubuklinggau. Jurnal Pendidikan Inndonesia. Vol. 4 No. 1: 96-109.

Purnomo, E.A, Dalyono. B \& Handayani. S, (2018). Pengembangan Media Pembelajaran Berbasis Android pada Mata kuliah Statistika Pendidikan. Jurnal Karya Pendidikan Matematika. $\quad 5 \quad$ (2). https://jurnal.unimus.ac.id/index.p hp/JPMat/article/view/4650/4188
Purnomo, E.A, Rohman, A \& Budiharto, (2015). Efektivitas Penerapan Model Pembelajaran Project Based Learning (PBL) Berbasis Maple Mata kuliah Kalkulus Lanjut II. Jurnal Karya Pendidikan Matematika. 2 (2) : 20-24. https://jurnal.unimus.ac.id/index.p hp/JPMat/article/view/1700/1749

Simonson, M., Smaldino, Sh., Albrigth, M., \& Zvacek, S. 2012. Teaching and learning at a distance. (5th ed.). Boston: Pearson Education. Inc

Sugiyono. 2013. Metode Penelitian Kuantitatif, Kualitatif dan R\&D. Bandung: ALFABET. 